\title{
Geochemical (REE and Trace elements) characteristics and tectonic setting discrimination of Permo-Carboniferous sandstone from Sikkim Lesser Himalaya, NE India
}

\author{
Raj Kumar Priya ${ }^{1}$, V. C. Tewari ${ }^{1}$, and R. K. Ranjan ${ }^{1}$
}

Received 16 April 2020; accepted 14 January 2021; published 13 September 2021.

The geochemical (REE \& traces elements) characteristics of Permo-Carboniferous sandstone has been taken into account to decipher tectonic setting and provenance of the Rangit Pebble Slate Formation of Sikkim Lesser Himalaya. The chondrite normalized REE pattern with Eu negative anomaly and a bivariate plot (Th/Co-La/Sc) clearly indicates that studied sediments were likely derived from upper crust felsic source. The average elemental ratio of traces elements La/Sc $(\sim 3.85), \mathrm{Th} / \mathrm{Sc}(\sim 2.57), \mathrm{Cr} / \mathrm{Th}(\sim 6.64), \mathrm{Th} / \mathrm{Co}(\sim 2.52), \mathrm{La} / \mathrm{Co}(\sim 3.74)$, and $\mathrm{Eu} / \mathrm{Eu}^{*}(\sim 0.32)$ also shows close affinities with Upper Continental Crust. The trivariate plot (La-Th-Sc plot, Th-Sc-Zr/10 plot, \& Th-Co-Zr/10 plot) and a bivariate plot (Ti/Zr-La/Sc) plotted on the field of passive tectonic region for the Rangit Pebble Slate Formation sandstone. A binary plot between the ratio of $\mathrm{Th} / \mathrm{Sc}-\mathrm{Zr} / \mathrm{Sc}$ and $\mathrm{Th} / \mathrm{U}-\mathrm{Th}$ reflects the enrichment of zircon and weathering trend during sedimentary recycling. KEYWORDS: Geochemistry; provenance; tectonic setting; Sikkim Lesser Himalaya; India.

Citation: Priya, Raj Kumar, V. C. Tewari, and R. K. Ranjan (2021), Geochemical (REE and Trace elements) characteristics and tectonic setting discrimination of Permo-Carboniferous sandstone from Sikkim Lesser Himalaya, NE India, Russ. J. Earth. Sci., 21, ES5002, doi:10.2205/2021ES000756.

\section{Introduction}

The Pre-Pleistocene glacial record of Earth as a whole was reviewed by Hambrey and Harland 2011. In this classical review they have covered almost all the glacial deposits of North and South America, Africa, Antarctica, Asia and Australia in East and West Gondwana land [Tewari and Sial, 2007]. Pre-Mesozoic global record of climate change of the earth was reviewed by Histon et al. 2013. The Neoproterozoic global glaciations (Snow Ball Earth) has been recorded from western Lesser Himalaya of India [Tewari, 2001, 2010. \footnotetext{
dia

${ }^{1}$ Geology Department, Sikkim University, Sikkim, In-
}

Copyright 2021 by the Geophysical Center RAS. http://rjes.wdcb.ru/doi/2021ES000756-res.html
2012. These are the main cryospheric events in the earth's history and well preserved in Indian subcontinent. The evidence of Late Paleozoic Gondwana glaciation is one of the important cryospheric event which have been documented from southern hemisphere. In, India it has been witnessed in both peninsular and extra-peninsular parts of Indian sub-continent. Rangit Gondwana Basin (RGB) of Sikkim Lesser Himalaya is one of the Himalayan Gondwana basin of eastern Himalaya in the Rangit window (Figure 1). Diamictites and boulder beds at the base of the Rangit Pebble Slate Formation shows the glacial environment based on field and petrography. The alternate bands of sandstone and shale overlying the glacial beds are influenced by the glacio-marine environment (Figure 2a, Figure $2 \mathrm{~b}$ ). The Rangit Pebble Slate Formation of the Sikkim Lesser Himalaya belongs to Lower Gondwana sequence and correlated with the Talchir For- 


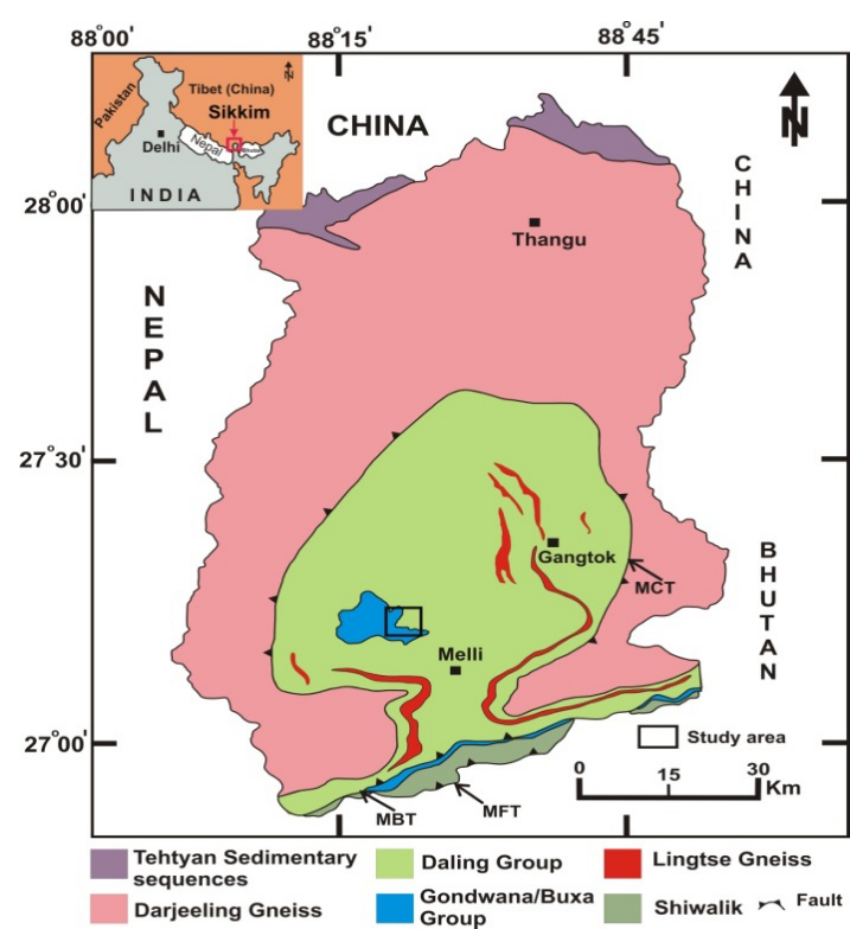

Figure 1. Geological map of the Sikkim Himalaya (after [Chakarborty et al., 2016, GSI, 2012]).

mation of Gondwana master basin in Peninsular India [Priya et al., 2019].

The main objective of the present study is to understand the source area composition, tectonic setting and paleo-weathering conditions during deposition of the Rangit Pebble-Slate (RPS) Formation. We have analyzed the REE and traces elements of the Rangit Pebble Slate Formation of Sikkim Lesser Himalaya and interpreted the data to achieve this objective. The distributions of REE pattern, elemental ratio, bivariate plot (Th/Co vs $\mathrm{La} / \mathrm{Sc}, \mathrm{Ti} / \mathrm{Zr}$ vs $\mathrm{La} / \mathrm{Sc}, \mathrm{La} / \mathrm{Th}$ vs $\mathrm{Th} / \mathrm{Yb}$, and $\mathrm{Th} / \mathrm{Sc}$ vs $\mathrm{Zr} / \mathrm{Sc}$ ) and a trivariate plot (La-Th-Sc, Th-Co-Zr/10 and Th-Sc-Zr/10) of traces elements have been significantly used to decipher the geochemical nature of provenance and discriminate tectonic setting of the studied sediments. A binary plot (Th/Sc vs Zr/Sc and Th/U vs Th) also have been used to measure the intensity of chemical weathering and sedimentary recycling.

\section{Material and Methods}

The systematic samples were collected from the Namchi-Sikkip area, Sikkim Lesser Himalaya studied area and powdered for the geochemical analysis. All the standard procedures have been followed for
Table 1. General Stratigraphic Column of Sikkim Himalaya [after Acharyya and Ray, 1977, GSI, 2012 Priya et al., 2019

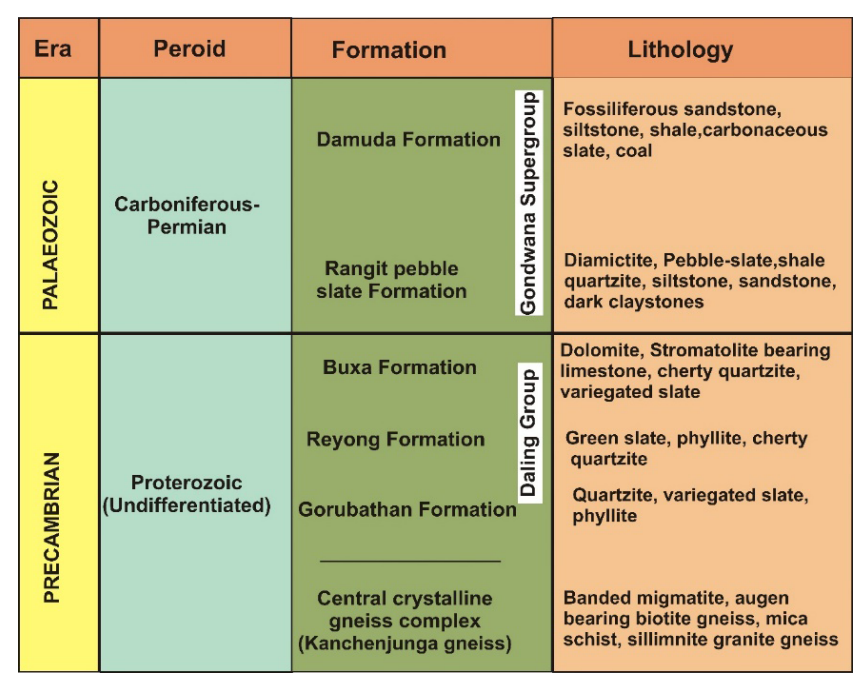

sample preparation [Takahashi, 2015]. Rare Earth Elements (REE) were analyzed using an Agilent 7700 Inductively Coupled Plasma Mass Spectrometer (ICP-MS) while traces element composition of the sample were determined by X-ray fluorescence (PANalytical, Axios ${ }^{\max }$ ) in the laboratory of Birbal Sahni Institute of Paleosceinces, Lucknow, India.

\section{Geological Setting of the Sikkim Lesser Himalaya}

The extra-peninsular geological formations exposed in the Rangit Window of Sikkim Lesser Himalaya includes the stromatolitic cherty dolomite and shales of Meso-Neoproterozoic Buxa Formation, the topmost formation of the Daling Group given in Table 1] [GSI, 2012; Schopf et al., 2008. Tewari, 2011]. The Paleo to Mesoproterozic Daling Group quartzites and phyllites underlie the Buxa Formation conformably in the Rangit window area [Priya et al., 2019]. Daling Group is further subdivided into Gorubathan (lower) Formation and Reyong (middle) Formation (Table 1). The unconformably overlying Permo-Carboniferous Gondwana Group of rocks primarily consists of glacial diamictites, pebble slates, sandstones and coal beds [Acharyya and Ray, 1977, GSI, 2012, Priya et al., 2019. The Damuda Group of the upper Gond- 

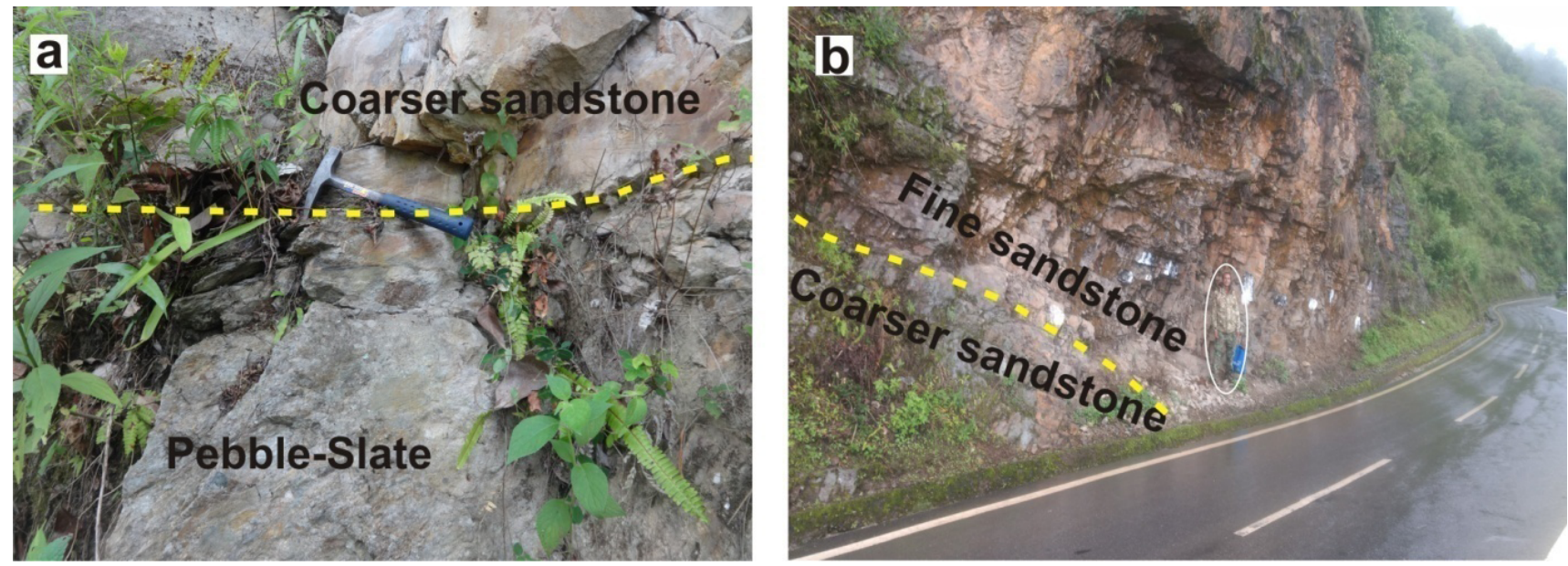

Figure 2. Field photograph depicting the Rangit Pebble Slate sequence in Sikkim Lesser Himalaya (a) alternate band of pebble-slate and coarser sandstone and (b) alternate band of coarser and fine sandstone.

wana mainly consists of phyllite, quartzite, variegated slates and dolomites [GSI, 2012. However, the dolomite is integral part of the underlying Buxa Group [Tewari, 2011]. Gondwana Group/Damuda Group of rocks (Carboniferous-Permian) is unconformably overlain by the stromatolitic and microfossiliferous cherty carbonate rocks of the Buxa Group [Priya et al., 2019, Schopf et al., 2008. Tewari, 2011. The Gondwana group of the sediments is the youngest stratigraphic unit in the Sikkim Lesser Himalaya which consists of two major formations i.e. Rangit Pebble Slate (RPS) Formation and Damuda Formation. The lower litho units mainly consists of pebble-slate, diamictites, coarser sandstone and olive-green shale. The upper Gondwana sediments (Namchi Sandstone) constitute the alternate bands of sandstone, fossiliferous shale and coal beds [Priya et al., 2019, Raichudhari, 2002.

The Rangit Pebble Slate Formation is exposed along Namchi-Sikkip road in South Sikkim. The Rangit Pebble Slate Formation belongs to the lower litho units of Gondwana Group. The Rangit Pebble Slate Formation is chiefly consists of glacial diamictite, boulder beds, pebble-slate, alternate band of sandstone and shale (Figure 2 2 , Figure $2 \mathrm{~b}$ ). The Rangit Pebble Slate sequence of the Sikkim Lesser Himalaya is tectonically disturbed, highly complex folding and over thrusting can be seen along the Namchi-Jorethang, Namchi-Sikkip and Namchi-Damthang road sections [Priya et al., 2021a; 2021b.

\section{Provenance and Tectonic Setting}

Trace and Rare earth elements (REE) is one of the most important geochemical tools which has been widely used to deciphering the sediment provenance, tectonic setting and depositional environment of any sedimentary geological Formation [Bhatia, 1983, Taylor and McLennan, 1985. Due to less mobility and highly resistant to the chemical weathering, some elements like Sc, Zr, Cr, Co, Th, V, and La are preserved as a geochemical signature to indicate the source of parents' materials [McLennan et al., 1983. The dominance of Sc, $\mathrm{V}$ and Co traces elements is higher in mafic source rock than felsic rock [Bhatia and Crook, 1986, Taylor and McLennan, 1985. The lower abundance of V, Sc and Co in all samples of RPS Fm. sandstones strongly suggests and confirms that these sandstones were derived from felsic source rock. The elemental ratio of traces elements such as La/Sc, $\mathrm{Th} / \mathrm{Sc}, \mathrm{Cr} / \mathrm{Th}, \mathrm{Th} / \mathrm{Co}$, and La/Co (Table 2 helps to distinguish and constrain the geochemical nature of the provenance [Culler, 2000, Taylor and McLennan, 1985 .

The value (elemental ratios) of studied samples of RPS Fm. sandstones shown more affinities towards felsic rocks derivation (Table 2). The high value of $\mathrm{Th} / \mathrm{Co}$ and $\mathrm{La} / \mathrm{Th}$ ratio in all studied samples have shown the enrichment of Th and La which significantly indicates that RPS Fm. sandstones were substantially derived from a felsic source. A bivariate plot between the ratio of $\mathrm{Th} / \mathrm{Co}$ vs 


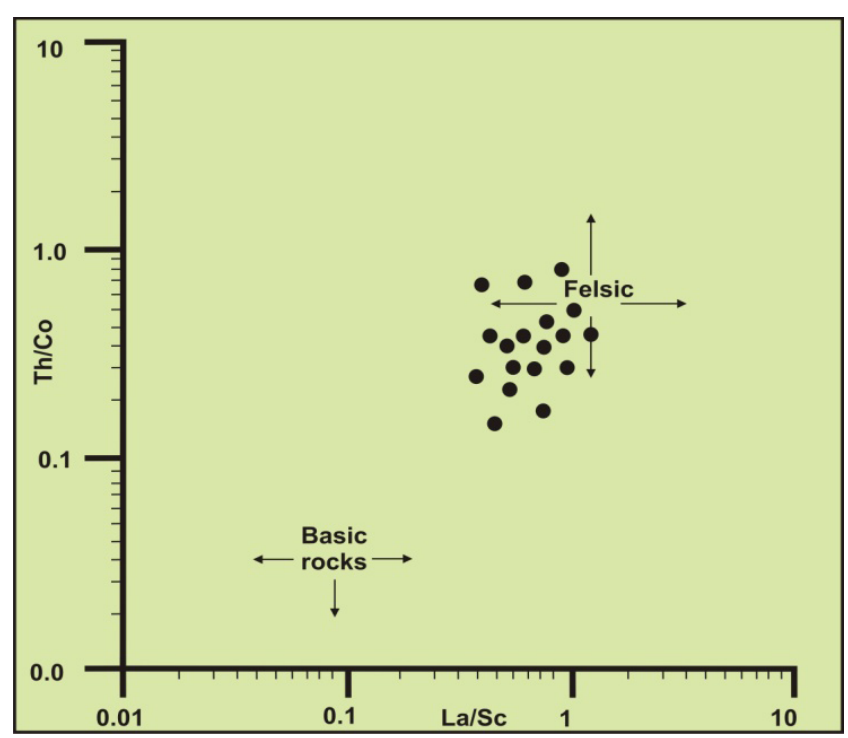

Figure 3. Bivariate plot of $\mathrm{Th} / \mathrm{Co}$ versus $\mathrm{La} / \mathrm{Sc}$ showing the felsic provenance of the studied sediments (after [Cullers, 2002]).

$\mathrm{La} / \mathrm{Sc}$ and $\mathrm{La} / \mathrm{Th}$ vs $\mathrm{Th} / \mathrm{Yb}$ Figure 3, Figure 5) also indicates that all studied sediments of Rangit Pebble Slate Formation were derived from the felsic source.

The total REE concentrations in the studied sample of Rangit Pebble Slate Formation sandstone ranged from $44.1 \mathrm{ppm}$ to $169.57 \mathrm{ppm}$ (Table 3) and were being normalized with normalizing factors of upper continental crust [Taylor and McLennan, 1985. In contrast, the high value of LREE/HREE ratio with negative Eu anomalies advocate felsic source rocks while mafic and/or ultramafic rocks have low LREE/HREE ratios with no or positive $\mathrm{Eu}$ anomalies [Taylor and McLennan, 1985. The REE distribution pattern of studied samples compared with UCC and shown the enrichment of light REE with a negative Eu anomaly (Figure 4).

The traces elements such as Sc, Co, La, Th, Ti and $\mathrm{Zr}$ play a significant role in deciphering the tectonic setting of clastic sedimentary rock. In the present study, triangular plots given by Bhatia and Crook 1986 have been used to discriminate the tectonic setting. The content of elements in the studied samples was converted into percentage and each axis of equilateral triangular plots equally divided into percentage (i.e. $0-100 \%$ ). The four distinctive tectonic settings i.e. Oceanic island arc (A), Continental island arc (B), Active continental margin (C) \& Passive margin (D) are recognized

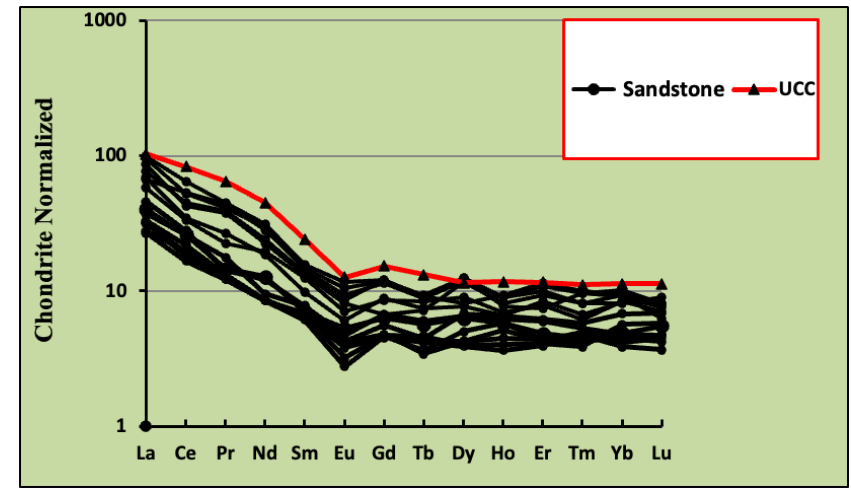

Figure 4. Chondrite-normalized REE pattern for RPS Fm. sandstone and comprehensive comparison with Upper Continental Crust (UCC) value (after [Taylor and McLennan, 1985).

on the triangular plot of La-Th-Sc, Th-Co-Zr/10 and Th-Sc-Zr/10. The differentiated tectonic environment (i.e. A, B, C, D) are demarcated on the basis of previous study done by Bhatia and Crook 1986] which indicate the relative dominance of traces elements in each of trivariate plots Figure $7 \mathrm{a}$, Figure $7 \mathrm{~b}$, Figure $7 \mathrm{k}$ ). The high value of Th/Sc ratio in the ternary plot of La-Th-Sc Figure $7 \mathrm{a}$ ) depicted the passive margin setting. The similar passive setting of the tectonic environment is also evident from triangular plot of Th-Co-Zr/10 and Th-Sc-Zr/10 (Figure 7b, Figure 7k). A bivariate plot between the ratio of $\mathrm{Ti} / \mathrm{Zr}$ and $\mathrm{La} / \mathrm{Sc}$ also imply passive tectonic setting (Figure 6). All these plots reflect the enrichments of Th \& Zr elements and depletion of Sc element in studied sediments of Rangit Pebble Slate Formation which indicate that these sediments were derived from the felsic provenance. The ratio of $\mathrm{Th}$ and $\mathrm{U}(\mathrm{Th} / \mathrm{U})$ reflects the signature of weathering and sedimentary recycling

Table 2. Comparative Study of the Elemental Ratios of Permo-Carboniferous Rangit Sandstone With Studied Sediments of Felsic Rock, Mafic Rocks and the Upper Continental Crust (UCC)

\begin{tabular}{l|llll}
\hline $\begin{array}{l}\text { Elemental } \\
\text { Ratio }\end{array}$ & $\begin{array}{l}\text { RPS Fm. } \\
\text { Sandstone }\end{array}$ & $\begin{array}{l}\text { Felsic } \\
\text { sources }^{a}\end{array}$ & $\begin{array}{l}\text { Mafic } \\
\text { sources }^{a}\end{array}$ & UCC $^{b}$ \\
\hline $\mathrm{La} / \mathrm{Sc}$ & $1.53-6.49$ & $2.50-16.3$ & $0.43-0.86$ & 2.21 \\
\hline $\mathrm{Th} / \mathrm{Sc}$ & $1.03-5.26$ & $0.84-20.5$ & $0.05-0.22$ & 0.79 \\
\hline $\mathrm{La} / \mathrm{Co}$ & $1.05-5.68$ & $1.80-13.8$ & $0.14-0.38$ & 1.76 \\
\hline $\mathrm{Th} / \mathrm{Co}$ & $0.57-12.2$ & $0.67-19.4$ & $0.04-1.40$ & 0.63 \\
\hline $\mathrm{Cr} / \mathrm{Th}$ & $3.23-13.5$ & $4.00-15.0$ & $25.00-50$ & 7.76 \\
\hline $\mathrm{Eu} / \mathrm{Eu}{ }^{*}$ & $0.21-0.47$ & $0.40-0.94$ & $0.71-0.95$ & 0.63 \\
\hline$\left[\begin{array}{l}{ }^{a} \text { Culler, } \\
2000\end{array}\right.$ & ${ }^{b}$ Taylor and McLennan, 1985. \\
\hline
\end{tabular}


Table 3. Chemical Composition (REE \& Traces) of Permo-Carboniferous Sandstone, Sikkim Lesser Himalaya, India

\begin{tabular}{|c|c|c|c|c|c|c|c|c|c|}
\hline $\begin{array}{l}\text { REE } \\
(\mathrm{ppm})\end{array}$ & Rsd1 & Rsd2 & Rsd3 & Rsd4 & Rsd5 & Rsd6 & Rsd7 & Rsd8 & Rsd9 \\
\hline La & 31.81 & 33.56 & 74.83 & 76.98 & 51.67 & 25.19 & 71.29 & 26.86 & 46.88 \\
\hline $\mathrm{Ce}$ & 61.29 & 51.21 & 50.29 & 43.15 & 41.05 & 33.31 & 32.11 & 24.97 & 26.95 \\
\hline $\mathrm{Pr}$ & 6.14 & 6.06 & 5.69 & 5.37 & 5.17 & 3.69 & 3.08 & 2.01 & 1.96 \\
\hline $\mathrm{Nd}$ & 22.21 & 19.91 & 21.03 & 17.05 & 16.12 & 13.23 & 14.02 & 9.07 & 8.61 \\
\hline Sm & 3.11 & 2.16 & 3.03 & 2.16 & 1.02 & 2.28 & 2.01 & 1.62 & 1.01 \\
\hline Eu & 1.01 & 0.91 & 0.81 & 0.75 & 0.71 & 0.53 & 0.61 & 0.52 & 0.41 \\
\hline Gd & 3.01 & 3.04 & 2.21 & 3.02 & 2.07 & 2.71 & 2 & 1.74 & 2.06 \\
\hline $\mathbf{T b}$ & 0.53 & 0.54 & 0.51 & 0.51 & 0.42 & 0.43 & 0.49 & 0.33 & 0.35 \\
\hline Dy & 3.09 & 4.76 & 4.73 & 4.56 & 4.42 & 2.95 & 3.41 & 2.39 & 2.51 \\
\hline Ho & 0.79 & 0.76 & 0.66 & 0.76 & 0.69 & 0.56 & 0.59 & 0.49 & 0.53 \\
\hline $\mathbf{E r}$ & 2.84 & 2.73 & 1.85 & 2.48 & 2.31 & 2.08 & 1.96 & 1.21 & 1.49 \\
\hline $\mathbf{T m}$ & 0.36 & 0.35 & 0.35 & 0.29 & 0.29 & 0.24 & 0.22 & 0.16 & 0.19 \\
\hline $\mathbf{Y b}$ & 2.34 & 2.51 & 3.29 & 4.82 & 6.97 & 4.04 & 5.91 & 6.21 & 4.88 \\
\hline Lu & 0.3 & 0.31 & 0.29 & 0.24 & 0.34 & 0.31 & 0.27 & 0.21 & 0.18 \\
\hline$\Sigma$ REE & 138.83 & 128.81 & 169.57 & 162.14 & 133.25 & 91.55 & 137.97 & 77.79 & 98.01 \\
\hline \multicolumn{10}{|l|}{$\begin{array}{l}\text { Traces } \\
\text { (ppm) }\end{array}$} \\
\hline Sc & 3.83 & 4 & 11.02 & 13.07 & 6.16 & 7.09 & 7.21 & 4.18 & 6.06 \\
\hline Rb & 0.24 & 1.34 & 0.84 & 0.8 & 0.26 & 1.54 & 0.29 & 1.49 & 0.34 \\
\hline $\mathrm{Ba}$ & 0.3 & 0.98 & 0.78 & 0.71 & 1.01 & 1.18 & 1.18 & 0.82 & 0.63 \\
\hline Th & 5.13 & 6.1 & 12.28 & 19.16 & 26.73 & 9.36 & 21.76 & 22.21 & 17.09 \\
\hline $\mathbf{U}$ & 1.13 & 1.89 & 3.02 & 2.69 & 2.82 & 1.31 & 2.86 & 1.97 & 2.98 \\
\hline $\mathrm{Cr}$ & 66.81 & 82.32 & 116.22 & 161.23 & 169.07 & 107.03 & 122.62 & 93.26 & 89.17 \\
\hline Co & 9.07 & 5.62 & 9.14 & 8.61 & 2.18 & 13.23 & 4.24 & 13.23 & 14.16 \\
\hline $\mathrm{Sr}$ & 1.25 & 0.15 & 0.12 & 0.62 & 0.12 & 0.23 & 0.16 & 0.14 & 0.05 \\
\hline Nd & 0.42 & 0.7 & 0.5 & 0.23 & 0.66 & 0.62 & 0.56 & 0.5 & 0.47 \\
\hline $\mathbf{P}$ & 0.69 & 0.12 & 0.9 & 0.25 & 0.75 & 0.81 & 1 & 0.56 & 0.87 \\
\hline Hf & 0.02 & 0.18 & 0.14 & 0.11 & 0.05 & 0.22 & 0.17 & 0.18 & 0.05 \\
\hline $\mathrm{Zr}$ & 149 & 136 & 141 & 118 & 147 & 139 & 111 & 91 & 116 \\
\hline $\mathbf{T i}$ & 115 & 226 & 424 & 346 & 538 & 478 & 642 & 562 & 654 \\
\hline $\mathbf{T b}$ & 0.81 & 1.42 & 1.22 & 0.45 & 1.16 & 1.12 & 0.98 & 0.95 & 0.86 \\
\hline $\mathbf{E u} / \mathbf{E u}{ }^{*}$ & 0.33 & 0.35 & 0.31 & 0.29 & 0.46 & 0.21 & 0.30 & 0.31 & 0.27 \\
\hline $\mathrm{La} / \mathrm{Sc}$ & 8.31 & 8.39 & 5.93 & 5.89 & 8.39 & 3.11 & 9.89 & 6.13 & 7.74 \\
\hline $\mathrm{Th} / \mathrm{Sc}$ & 1.34 & 1.53 & 0.97 & 1.47 & 4.34 & 1.16 & 3.02 & 5.07 & 4.47 \\
\hline $\mathrm{La} / \mathrm{Co}$ & 1.08 & 4.09 & 3.52 & 3.26 & 14.53 & 1.90 & 5.02 & 2.03 & 2.60 \\
\hline Th/Co & 0.57 & 1.09 & 1.34 & 2.23 & 12.26 & 0.71 & 5.13 & 1.68 & 1.91 \\
\hline $\mathrm{Cr} / \mathrm{Th}$ & 13.02 & 13.50 & 9.46 & 8.41 & 6.33 & 11.43 & 5.64 & 4.20 & 3.29 \\
\hline $\mathrm{La} / \mathrm{Sc}$ & 8.31 & 8.39 & 6.79 & 5.89 & 8.39 & 3.55 & 9.89 & 6.43 & 7.74 \\
\hline Th/Yb & 2.19 & 2.43 & 3.73 & 3.98 & 3.84 & 2.32 & 3.68 & 3.58 & 3.50 \\
\hline $\mathrm{Ti} / \mathrm{Zr}$ & 0.77 & 1.66 & 3.01 & 2.93 & 3.66 & 3.44 & 5.78 & 6.18 & 5.64 \\
\hline $\mathrm{La} / \mathrm{Th}$ & 6.20 & 5.50 & 6.09 & 4.02 & 1.93 & 2.69 & 3.28 & 1.21 & 2.74 \\
\hline
\end{tabular}


Table 3. Chemical Composition (REE \& Traces) of Permo-Carboniferous Sandstone, Sikkim Lesser Himalaya, India

\begin{tabular}{|c|c|c|c|c|c|c|c|c|c|}
\hline \multicolumn{10}{|c|}{ Continue. } \\
\hline $\begin{array}{l}\text { REE } \\
(\mathrm{ppm})\end{array}$ & Rsd10 & Rsd11 & Rsd12 & Rsd13 & RMd14 & RMd15 & Rsd16 & RMd17 & RMd18 \\
\hline La & 60.72 & 11.64 & 38.08 & 11.76 & 13.21 & 9.87 & 25.56 & 34.82 & 35.08 \\
\hline $\mathrm{Ce}$ & 24.87 & 18.63 & 21.07 & 17.21 & 19.07 & 16.01 & 41.05 & 24.87 & 26.95 \\
\hline Pr & 2.42 & 1.73 & 1.81 & 1.68 & 1.71 & 1.67 & 5.17 & 2.42 & 1.96 \\
\hline Nd & 6.79 & 6.04 & 6.12 & 6.03 & 6.11 & 6.09 & 15.02 & 6.79 & 9.01 \\
\hline Sm & 1.79 & 1.41 & 1.52 & 1.06 & 1.54 & 1.51 & 1.02 & 1.79 & 1.01 \\
\hline Eu & 0.42 & 0.54 & 0.36 & 0.49 & 0.48 & 0.38 & 0.51 & 0.41 & 0.42 \\
\hline Gd & 1.03 & 1.41 & 1.46 & 1.03 & 1.43 & 1.39 & 1.24 & 1.03 & 2.06 \\
\hline $\mathrm{Tb}$ & 0.26 & 0.21 & 0.2 & 0.25 & 0.27 & 0.24 & 0.39 & 0.24 & 0.36 \\
\hline Dy & 2.59 & 1.92 & 1.61 & 1.63 & 1.52 & 1.49 & 4.41 & 2.46 & 2.51 \\
\hline Ho & 0.56 & 0.49 & 0.44 & 0.38 & 0.34 & 0.31 & 0.69 & 0.56 & 0.44 \\
\hline Er & 1.54 & 1.09 & 1.07 & 1.09 & 1.02 & 0.98 & 2.03 & 1.26 & 1.38 \\
\hline $\mathbf{T m}$ & 0.21 & 0.17 & 0.18 & 0.15 & 0.14 & 0.17 & 0.29 & 0.21 & 0.19 \\
\hline $\mathrm{Yb}$ & 5.89 & 2.84 & 2.11 & 4.16 & 2.41 & 1.96 & 5.92 & 3.69 & 1.88 \\
\hline Lu & 0.26 & 0.17 & 0.16 & 0.18 & 0.22 & 0.14 & 0.22 & 0.23 & 0.15 \\
\hline$\Sigma$ REE & 109.35 & 48.29 & 76.19 & 47.1 & 49.47 & 42.21 & 103.52 & 80.78 & 83.4 \\
\hline \multicolumn{10}{|l|}{$\begin{array}{l}\text { Traces } \\
(\mathrm{ppm})\end{array}$} \\
\hline Sc & 6.81 & 2.03 & 7.87 & 5.83 & 5.98 & 6.02 & 4.46 & 3.06 & 4.72 \\
\hline $\mathbf{R b}$ & 1.37 & 0.36 & 0.61 & 0.53 & 0.78 & 1.55 & 0.83 & 0.57 & 0.81 \\
\hline $\mathrm{Ba}$ & 0.46 & 0.87 & 0.98 & 0.97 & 1.22 & 1.1 & 0.56 & 1.02 & 0.41 \\
\hline Th & 20.03 & 8.38 & 4.78 & 9.16 & 6.13 & 5.99 & 22.21 & 13.02 & 4.87 \\
\hline $\mathbf{U}$ & 2.96 & 1.99 & 0.9 & 1.04 & 1.39 & 0.95 & 1.87 & 1.05 & 0.67 \\
\hline $\mathrm{Cr}$ & 41.69 & 51.81 & 27.23 & 58.23 & 39.11 & 28.33 & 85.17 & 42.05 & 28.33 \\
\hline Co & 9.84 & 11.06 & 7.04 & 2.26 & 4.18 & 3.13 & 6.03 & 6.79 & 2.53 \\
\hline $\mathrm{Sr}$ & 0.03 & 0.13 & 0.18 & 0.15 & 0.23 & 0.04 & 0.02 & 0.05 & 0.12 \\
\hline $\mathrm{Nd}$ & 0.73 & 0.27 & 0.35 & 0.35 & 0.31 & 0.25 & 0.41 & 0.32 & 0.54 \\
\hline $\mathbf{P}$ & 1 & 0.5 & 0.81 & 1.06 & 0.37 & 0.44 & 0.12 & 0.42 & 0.22 \\
\hline Hf & 0.15 & 0.21 & 0.22 & 0.35 & 0.27 & 0.15 & 0.19 & 0.07 & 0.15 \\
\hline $\mathrm{Zr}$ & 89 & 126 & 81 & 151 & 79 & 152 & 109 & 98 & 114 \\
\hline $\mathbf{T i}$ & 258 & 522 & 654 & 463 & 466 & 567 & 651 & 632 & 524 \\
\hline $\mathrm{Tb}$ & 1.58 & 0.55 & 0.64 & 0.62 & 0.58 & 0.5 & 0.71 & 0.29 & 0.38 \\
\hline $\mathbf{E u} / \mathbf{E u} *$ & 0.30 & 0.38 & 0.24 & 0.47 & 0.32 & 0.26 & 0.45 & 0.29 & 0.27 \\
\hline $\mathrm{La} / \mathrm{Sc}$ & 15.94 & 5.73 & 4.84 & 2.02 & 2.21 & 1.64 & 4.68 & 11.38 & 7.43 \\
\hline $\mathrm{Th} / \mathrm{Sc}$ & 5.26 & 4.13 & 0.61 & 1.57 & 1.03 & 1.00 & 4.07 & 4.25 & 1.03 \\
\hline $\mathrm{La} / \mathrm{Co}$ & 2.51 & 1.05 & 1.72 & 5.20 & 3.16 & 3.15 & 4.24 & 2.48 & 5.68 \\
\hline Th/Co & 2.04 & 0.76 & 0.68 & 4.05 & 1.47 & 1.91 & 3.68 & 1.92 & 1.93 \\
\hline $\mathrm{Cr} / \mathrm{Th}$ & 2.08 & 6.18 & 5.70 & 6.36 & 6.38 & 4.73 & 3.83 & 3.23 & 5.81 \\
\hline $\mathrm{La} / \mathrm{Sc}$ & 8.92 & 5.73 & 4.84 & 2.02 & 2.21 & 1.64 & 5.73 & 11.38 & 7.43 \\
\hline $\mathrm{Th} / \mathrm{Yb}$ & 3.40 & 2.95 & 2.27 & 2.20 & 2.54 & 3.06 & 3.75 & 3.53 & 2.59 \\
\hline $\mathrm{Ti} / \mathrm{Zr}$ & 2.90 & 4.14 & 8.07 & 3.07 & 5.90 & 3.73 & 5.97 & 6.45 & 4.60 \\
\hline $\mathrm{La} / \mathrm{Th}$ & 3.03 & 1.39 & 7.97 & 1.28 & 2.15 & 1.65 & 1.15 & 2.67 & 7.20 \\
\hline
\end{tabular}




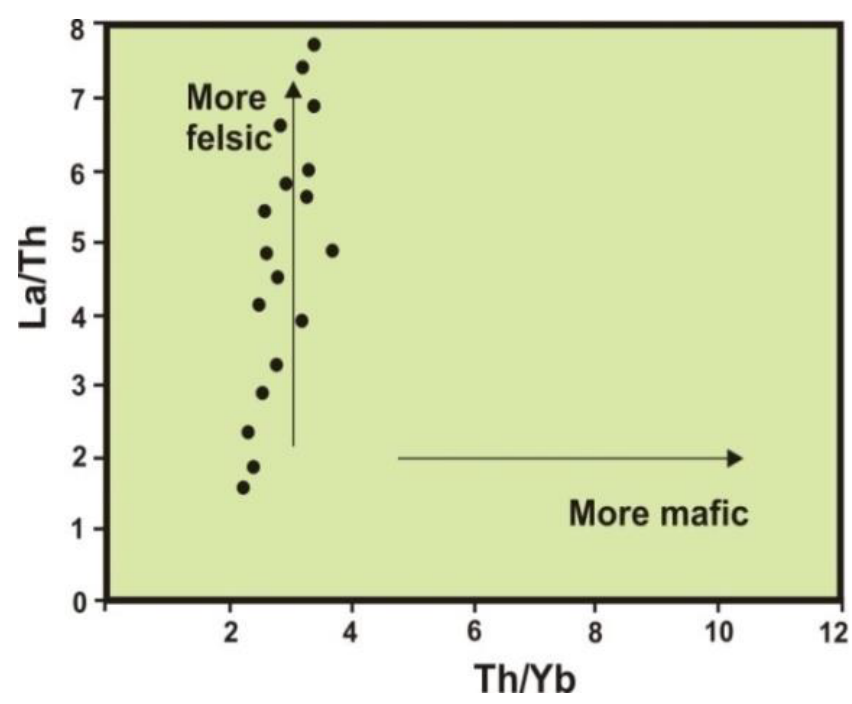

Figure 5. A bivariate plot ( $\mathrm{La} / \mathrm{Th}$ vs $\mathrm{Th} / \mathrm{Yb})$ for the Permo-Carboniferous sandstone of Rangit Pebble Slate Formation, Sikkim Lesser Himalaya (after Taylor and McLennan, 1985).

histories due to loss of $\mathrm{U}^{4+}$ during sedimentation [Taylor and McLennan, 1985]. If the ratio value of $\mathrm{Th} / \mathrm{U}$ is higher than 4.0 then, it is considered to be result of high intensity of weathering and/or sediment recycling in the provenance area [Rahman and Suzuki, 2007]. In the present study, a binary plot between the ratio of $\mathrm{Th} / \mathrm{U}$ vs $\mathrm{Th}$ and $\mathrm{Th} / \mathrm{Sc}$ vs $\mathrm{Zr} / \mathrm{Sc}$ have been used to shown the weathering trend and sedimentary recycling for the RPS Fm. sandstone (Figure 8, Figure 9). The elemental ratio $(\mathrm{Th} / \mathrm{U})$ of RPS Fm. sandstones ranges 3.17 to 7.39 with an average of 4.8 which implies that these sediments were influenced by weathering and sedimentary recycling (Figure 8). Furthermore, a binary plot between the ratios of $\mathrm{Th} / \mathrm{Sc}$ and $\mathrm{Zr} / \mathrm{Sc}$ is another reliable indicator has been used to measure the role of sorting and sedimentary recycling [McLennan et al., 1983. The addition of zircon in studied sample significantly correlated with a bivariate plot of $\mathrm{Th} / \mathrm{Sc}$ vs $\mathrm{Zr} / \mathrm{Sc}$ which might be the consequences of sedimentary recycling (Figure 9).

\section{Results and Discussion}

The distributions of rare earth element (REE) and traces elements of clastic sedimentary rock have been broadly applied for characterizing the provenance and tectonic setting discrimination

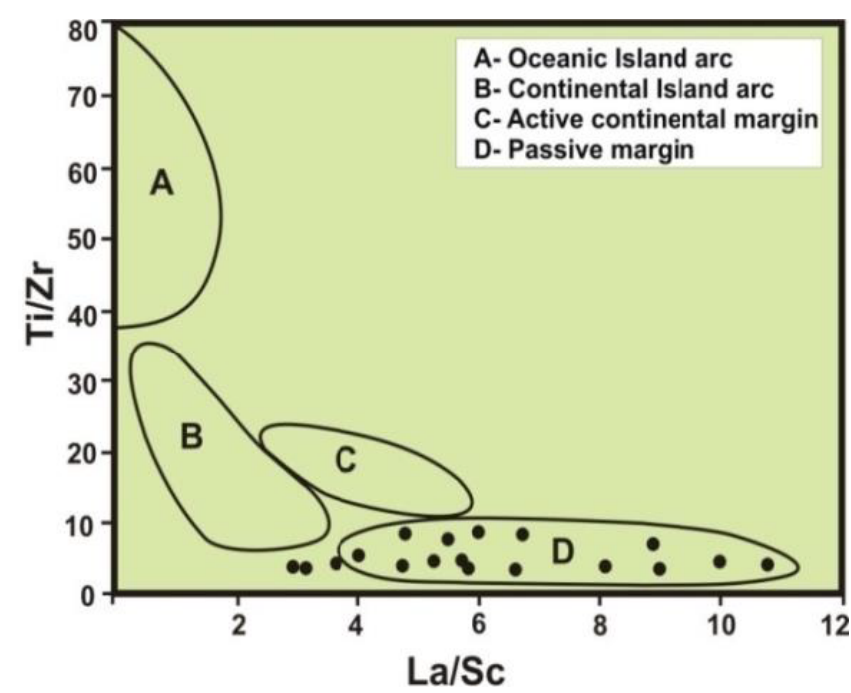

Figure 6. A bivariate tectonic setting discrimination diagram for sandstone of RPS Fm. (after [Bhatia and Crook, 1986]).

[McLennan et al., 1993. The elemental ratios (Table 2 of trace elements have been positively used for the comparative study with felsic source, mafic source and UCC to interpret the geochemical nature of sediment. The dominance of Th and $\mathrm{Zr}$ elements in the studied sediments strongly indicate felsic provenance which has been depicted through a binary plot of Th/Co vs La/Sc and La/Th vs
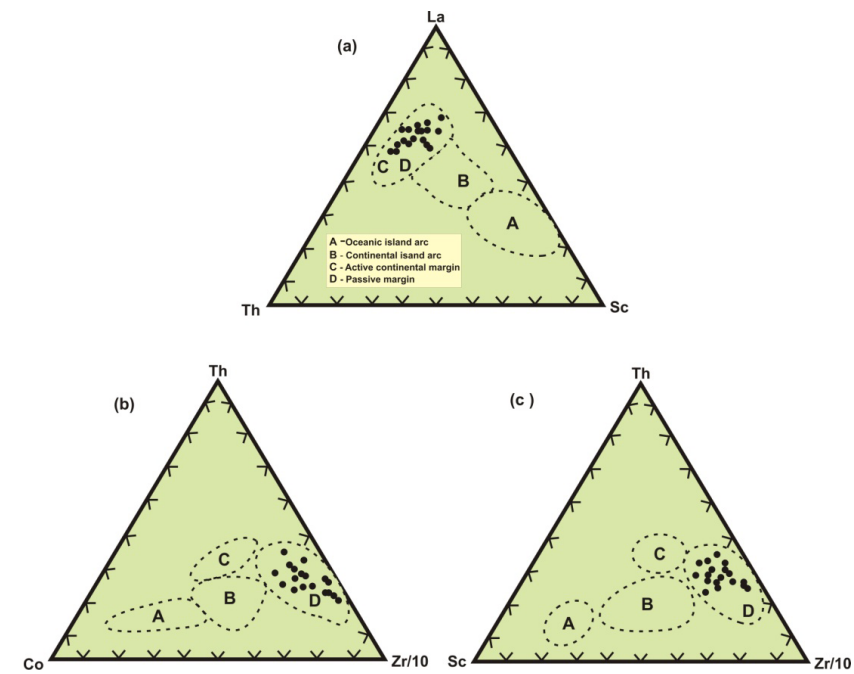

Figure 7. A ternary plot ( $a, b$ \& c) for tectonic setting showing the passive tectonic environment for Permo-Carboniferous sandstone of Rangit Pebble Slate Formation, Sikkim Lesser Himalaya (after [Bhatia and Crook, 1986]). 


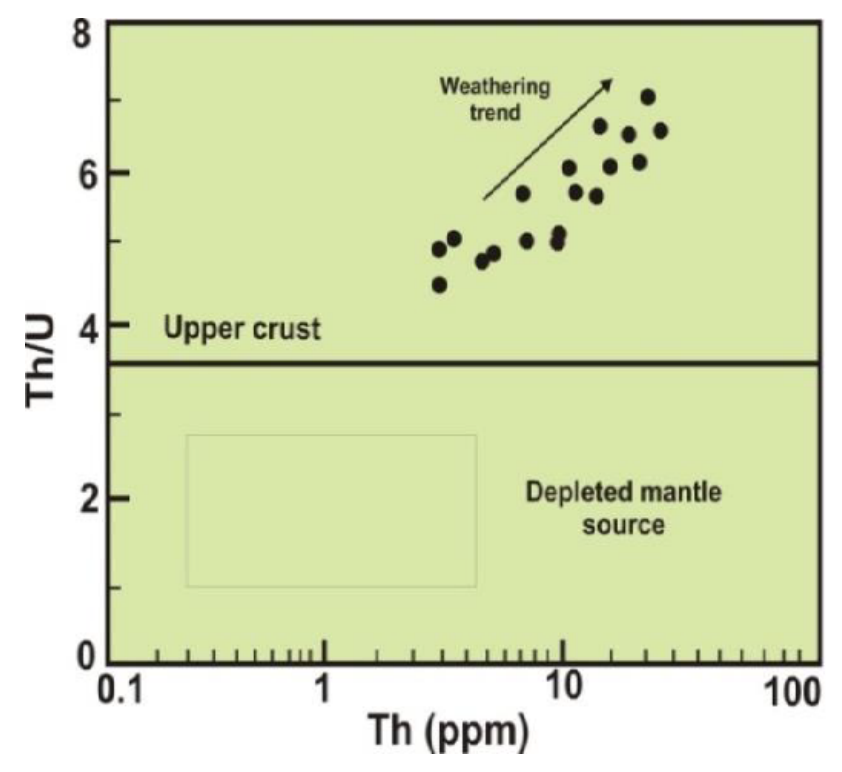

Figure 8. Binary plot of $\mathrm{Th} / \mathrm{U}$ versus $\mathrm{Th}$ for the RPS Formation sandstone (after [McLennan et al., 1993 ).

Th/Yb (Figure 3, Figure 5). The REE distribution pattern of studied samples shows the enrichment of light REE with a negative Eu anomaly which implied the felsic rich source derivation (Figure 4). The triangular plot of La-Th-Sc, Th-Co-Zr/10 and Th-Sc-Zr/10 (Figure 7a, Figure 7b, Figure 7c) indicate the passive margin tectonic environment of deposition. A typical weathering trend depicted by the bivariate plot of Th/U vs $\mathrm{Th} / \mathrm{U}$ and $\mathrm{Th} / \mathrm{Sc}$ vs $\mathrm{Zr} / \mathrm{Sc}$ strongly supports the role of weathering and sedimentary recycling during the sedimentation of RPS Formation (Figure 8, Figure 9).

\section{Conclusion}

The Permo-Carboniferous sandstone of the Rangit Pebble Slate Formation of Sikkim Lesser Himalaya has been studied to decipher its geochemical characteristics through REE and trace elements. The discrimination diagram for provenance and tectonic setting, elucidate that these sediments were derived from felsic rich provenance (continental) and were deposited in a passive continental tectonic setting. The combined results of both REE and trace elements indicate the felsic source which may have been derived from high grade metamorphic rocks and plutonic igneous rocks of Peninsular Craton i.e. Chotanagpur Granite Gneiss Com-

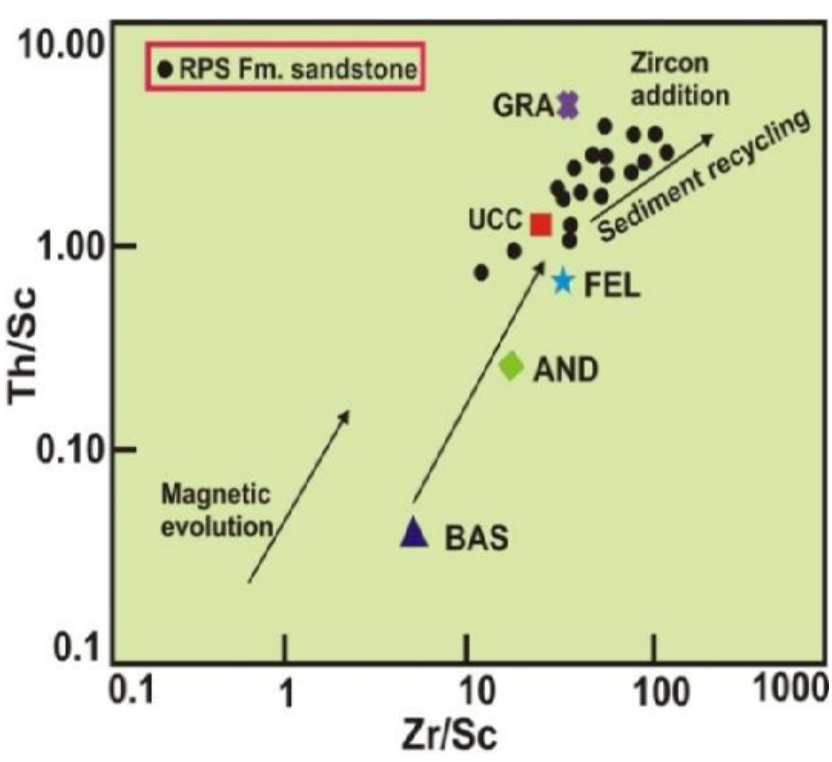

Figure 9. Binary plot of $\mathrm{Th} / \mathrm{Sc}$ versus $\mathrm{Zr} / \mathrm{Sc}$ for the RPS Fm. sandstones (after [McLennan et al., 1993). Different geometry symbol indicate the average composition of basalt (BAS), andesite (AND), felsic (FEL), granite (GRA) and upper continental crust (UCC).

plex (CGGC), Shillong-Meghalaya Gneissic Complex (SMGC) and Proterzoic Himalayan granites and gneisses rock. The higher LREE pattern with negative $\mathrm{Eu}$ anomaly and elemental ratios of trace elements of Rangit Pebble Slate Formation sandstone strongly suggest that these sediments are enriched with felsic source rock and closely associated with upper continental crust (UCC). A typical weathering trend depicted by $\mathrm{Th} / \mathrm{Sc}$ vs $\mathrm{Zr} / \mathrm{Sc}$ and $\mathrm{Th} / \mathrm{U}$ vs $\mathrm{Th}$ plot suggested that these sediments were strongly influenced by weathering and sedimentary recycling during sedimentation.

Acknowledgment. The authors are thankful to the Head of Department, Sikkim University for his constant support and providing infrastructural facilities. Director, Birbal Sahni Institute of Palaeoscience, Lucknow, India is thanked for providing the facilities of the geochemical laboratory of the Institute. We are grateful to Dr. N. Wanjari for discussions and suggestions. Anonymous reviewer is thanked for constructive comments and valuable suggestions to improve themanuscript. R.K.P. thanks Sikkim University for award of research fellowship to carry out this research. 


\section{References}

Acharyya, S. K., K. K. Ray (1977), Geology of the Darjeeling-Sikkim Himalaya, guide to excursion, 4th Internat. Gond. Symp. India, No. 4, 23.

Bhatia, M. R. (1983), Plate tectonics and geochemical composition of sandstones, J. Geol., 91, No. 6, 611-627, Crossref

Bhatia, M. R., K. A. W. Crook (1986), Trace element characteristics of graywackes and tectonic setting discrimination of sedimentary basins, Contribution to Mineralogy and Petrology, 92, 181-193, Crossref

Chakraborty, S., R. Anczkiewicz, et al. (2016), A review of thermal history and timescales of tectonometamorphic processes in Sikkim Himalaya (NE India) and implications for rates of metamorphic processes, Journal of Metamorphic Geology, 34, 785-803, Crossref

Cullers, R. L. (2000), The geochemistry of shales, siltstones and sandstones of Pennsylvanian-Permian age, Colorado, USA: Implications for provenance and metamorphic studies, Lithos, 51, 181-203, Crossref

Cullers, R. L. (2002), Implications of Elemental Concentrations for Provenance, Redox Conditions, and Metamorphic Studies of Shales and Limestones near Pueblo CO, USA, Chemical Geology, 191, 305-327, Crossref

Geological Survey of India (2012), Geology and mineral resources of the state of India, Miscellaneous Publication, No. 30, Part 19, 19-21.

Hambrey, M. J., H. B. Harland, (Eds.) (2011), Earth's Pre Pleistocene Glacial Records, 1022 pp. Cambridge University Press, Cambridge.

Histon, K., V. C. Tewari, M. Melchin, (Eds.) (2013), Pre Mesozoic Climate and Global Change. Special Issue: Pre Mesozoic Climates and Global Change, Palaeogeography, Palaeoclimatology, Palaeocecology, 1-3, Crossref

McLennan, S. M., S. Hemming, et al. (1993), Geochemical approaches to sedimentation, provenance, and tectonics, Geol. Soc. Amer., Spec. Paper, 284, 21-40, Crossref

McLennan, S. M., S. R. Taylor, K. A. Eriksson (1983), Geochemistry of Archean shales from the Pilbara Supergroup, Western Australia, Geochim. Cosmochim. Acta, 47, 1211-1222, Crossref

Taylor, S. R., S. M. McLennan (1985), The Continental Crust: Its Composition and Evolution, Blackwell Publishing, Oxford, UK.

Priya, R. K., V. C. Tewari, R. K. Ranjan (2019), Permian Tethyan transgression in Sikkim-Darjeeling Himalaya with special reference to the Paleoclimatic event, Bulletin of Nepal Geological Society, 36, 233240.

Priya, R. K., V. C. Tewari, R. K. Ranjan (2021a), Geochemical and Petrological Studies of Permo-Carboniferous Sandstones from the Rangit Pebble-Slate
Formation, Sikkim Lesser Himalaya, India: Implication for Provenance, Tectonic Setting, and Paleoclimate, Geological Bulletin of Turkey, 64, 129-142, Crossref

Priya, R. K., V. C. Tewari, R. K. Ranjan (2021b), Permo-Carboniferous Climate Change: Geochemical Evidences from Lower Gondwana Glacial Sediments, Rangit Valley, Sikkim Lesser Himalaya, India, Journal of Climate Change, 7, No. 1, 1-11, Crossref

Rahman, M. J. J., S. Suzuki (2007), Geochemistry of sandstones from the Miocene Surma Group, Bengal Basin, Bangladesh: Implications for provenance, tectonic setting and weathering, Geochem. J., 41, 415-428, Crossref

Raichudhari, A. K. (2002), Study of marine megainvertebrates of the Permian rocks of Darjeeling-Sikkim Himalya, Geol. Surv. India, E.R., 133, No. 3, 25-26.

Schopf, J. W., V. C. Tewari, A. Kudryavtsev (2008), Discovery of a New Chert - permineralized microbiota in the Proterozoic Bux Formation of the Ranjit Window, Sikkim, N.E. India, and its Astrobiological Implications, Astrobiology, 8, 735-746, Crossref

Taylor, S. R., S. M. McLennan (1985), The continental crust: Its composition and evolution, 1312 pp. Blackwell, London.

Takahashi, G. (2015), Sample preparation for X-ray fluorescence analysis III. Pressed and loose powder methods, Rigaku Journal, 31/1, 26-30.

Tewari, V. C. (2001), Neoproterozoic glaciation in the Uttaranchal Lesser Himalaya and the global palaeoclimate change. National Symposium on role of Earth Sciences in Integrated Development and Related Societal Issues, G.S.I. Spl. Publ., 65, No. III, 49-56.

Tewari, V. C. (2010), Stratigraphy, Sedimentation and Depositional environment of Neoproterozoic-Early Cambrian Sedimentary basins of the Lesser Himalaya, India, Gondwana Geological Magazine, 12, 101112.

Tewari, V. C. (2011), Stromatolites , organic walled microorganisms , Laser Raman Spectroscopy and Confocal Laser Scanning Microscopy of the MesoNeoproterozoic Buxa Formation, Ranjit Window, Sikkim Lesser Himalaya, NE India, Astrobiology, 18, 495-524, Crossref

Tewari, V. C. (2012), Neoproterozoic Blaini glacial diamictite and Ediacaran Krol carbonate sedimentation in the Lesser Himalaya, India, Geological Society of London, Special Publication On Line First, 366, Crossref

Tewari, V. C., A. N. Sial (2007), NeoproterozoicEarly Cambrian isotopic variation and chemostratigraphy of the Lesser Himalaya, India, Eastern Gondwana, Chemical Geology and Isotope Geoscience, 237, No. 1-2, 64-88, Crossref

\section{Corresponding author:}

Raj Kumar Priya, Geology Department, Sikkim University, 6th Mile, Tadong, Gangtok, Sikkim, India. (rajkumarpriya16@gmail.com) 